\title{
THERMOBARIC CONDITIONS OF OIL AND GAS CONTENTS AND PREDICTING OF HYDROCARBON PHASE STATE (ON THE EXAMPLE OF THE BILCHE-VOLYTSA OIL- AND GAS-BEARING AREA)
}

\begin{abstract}
О. В. Любчак, І. В. Колодій, Ю. В. Хоха. ТЕРМОБАРИЧНІ УМОВИ НАФТОГАЗОНОСНОСТІ ТА ПРОГНОЗУВАННЯ ФАЗОВОГО СТАНУ ВУГЛЕВОДНІВ (НА ПРИКЛАДІ БІЛЬЧЕ-ВОЛИЦЬКОГО НАФТОГАЗОВОГО РАЙОНУ). Проведений аналіз розподілу термобаричних параметрів покладів вуглеводнів. За розподілом геотермічних параметрів досить чітко виділяються два різних за геотермічною активністю райони: північно-західний, більи прогрітий, $і$ південносхідний - відносно "холодний". Максимальні температури відмічаються по лінії газоносних структур, изо тяжіють до північно-західної приплатформової частини Зовнішньої зони.

Показано, щяо характер зміни коефічієнта гідростатичності залежить від особливостей структурно-тектонічноі будови досліджуваної території.

Оцінка фазового стану вуглеводнів спиралась на проведенні аналізу розмірностей їхніх фізико-хімічних властивостей та термобаричних умов залягання для вільних газів, конденсатів та нафт з понад 200 об'єктів, щцо дали припливи флюїдів на родовищах Більче-Волицького нафтогазового району.

На основі проведеного аналізу виведені критерії $Z_{1}$ та $Z_{2}$, які визначають фазовий стан суміші вуглеводнів у покладі. Визначені області числових значень цих критерії, які характеризують типи вуглеводневих систем та дозволяють, за наявності інформації щуодо глибини залягання покладу, густини і молярної маси вуглеводнів, а також температури і тиску, встановити фазовий стан вуглеводневої системи. Встановлено, шуо на глибинах більших за 4000 м, в залежності від геологічних умов, спостерігаються відхилення значень $Z_{l}{ }^{a}$ від середнього в межах до $20 \%$.

Доведена універсальність л-теореми, яка дозволяє вводити і інші параметри щуо характеризують вуглеводневі системи, щьо суттєво розширяє та покрашує визначення критеріїв їхньої подібності, необхідних для прогнозування фазового стану вуглеводнів у різних геологічних умовах.

Ключові слова: Більче - Волищький нафтогазоносний район, вуглеводнева система, термобаричні умови, коефіцієнт гідростатичності, фазовий стан вуглеводнів, $\pi$ - теорема, аналіз розмірності.
\end{abstract}

А. В. Любчак, И. В. Колодий, Ю.В. ХоХа. ТЕРМОБАРИЧЕСКИЕ УСЛОВИЯ НЕФТЕГАЗОНОСНОСТИ И ПРОГНОЗИРОВАНИЯ ФАЗОВОГО СОСТОЯНИЯ УГЛЕВОДОРОДОВ (НА ПРИМЕРЕ БИЛЬЧЕ-ВОЛЬЦКОГО НЕФТЕГАЗОВОГО РАЙОНА). Проведен анализ распределения термобарических параметров месторождений углеводородов. По распределению геотермических параметров достаточно четко выделяются два разных по геотермической активности района: северо-западный, более прогретый и юго-восточный - относительно "холодный". Максимальные температуры отмечаются по линии газоносных структур, тяготеют к северо-западной приплатформенной части Внешней зоны.

Показано, что характер изменения коэффициента гидростатичности зависит от особенностей структурнотектонического строения исследуемой территории.

Оиенка фазового состояния углеводородов базировалась на проведении анализа размерностей их физико-химических свойств и термобарических условий залегания свободных газов, конденсатов и нефтей для более чем 200 объектов, которыле дали припльв флюидов из месторождений Бильче-Вольцкого нефтегазоносного района.

На основе проведенного анализа выведены критерии $Z_{1}$ и $Z_{2}$, которые определяют фазовое состояние смеси углеводородов в залежи. Определены области числовых значений этих критериев, характеризующих типы углеводородных систем, которые позволяют, при наличии информации относительно глубины залегания залежи, плотности и молярной массы углеводородов, а также температуры и давления, установить фазовое состояние углеводородной системы. Установлено, что на глубинах превышаюших $4000 \mathrm{M}$, в зависимости от геологических условий, наблюдаются отклонения значений $Z_{1}{ }^{\circ}$ от среднего в пределах до $20 \%$.

Доказана универсальность л-теоремы, которая позволяет вводить другие параметры характеризующие углеводородные системы, что существенно расширит и улучиит установление критериев их подобия, необходимых для прогнозирования фазового состояния углеводородов в различных геологических условиях.

Ключевые слова: Бильче-Вольцикий нефтегазоносный район, углеводородная система, термобарические условия, коэффициент гидростатичности, фазовое состояние углеводородов, л-теорема, анализ размерностей.

Significance (Practical Value). When planning the search, prospecting and exploration of oil and gas fields, the establishment of the hydrocarbons system phase state plays an important role. Understanding features of phase transformations is necessary when planning developments of bed, industrial processing of useful hydrocarbon raw material and petroleum transportation. The information about the phase state is necessary while assessing the hydrocarbons reserves and planning measures to increase the coefficient of their extraction from the beds in different geological conditions.
We tried to create a method to establish hydrocarbons phase state in the geological environment to increase the efficiency of measuring oil and gas parameters.

The basic theorem of the dimension analysis method, namely $-\pi$ - theorem, in application to the physical parameters that describe the hydrocarbon systems (natural gases, gas-condensate, and oil) was used in our work. It was necessary to conduct the analysis of the parameters dimension describing the hydrocarbons natural systems in the course of processing. In the future, criteria that determine the 
phase state of hydrocarbons mixture in the roof of the bed are defined on their basis.

Previous investigations. It is accepted that the most accurate information on the phase states of hydrocarbon systems can be obtained by thermodynamics [1]. This method is based on scientific fundamentals and conforms to mathematic simulation as a necessary step from theory to practice. Solutions are described in literature [1-4], including algorithms of phase transformations in hydrocarbon systems depending on their composition and P-V-T (pressure-volume-temperature) behaviors of geology environment. Sometimes, these models include capillary phenomena in the reservoirs, gravity influence, multi-component filtration under high pressure conditions for deposits at significant depths. It should be noted, that complicated theoretical basis, multiple approximations, and problems in properties comprehended for mixtures in P-V-T dependence, are the reasons of hard transformation from pure theory into practical applications.

Apart from the attempts to determine phase state and phase transfigurations (transitions) in gascondensate and petroleum systems by means of thermodynamic methods $[4,5]$ laboratory methods and selection of deep fluids samples from formation were proposed. We carried out laboratory investigations of formational hydrocarbon systems as well as data of thermobaric conditions of their location in sediments.

Results of the study. Estimations of hydrocarbon phase state were supported by analysing dimensions of their physical-chemical properties and thermobaric conditions of free gases, condensates and oil (petroleum) from more than 200 locations which supplied fluids to the deposits of BilcheVolytsa oil- and gas-bearing area [6]. Selected physical parameters for bed petroleum and gascondensate systems were determined from deep samples in the laboratory of LB UkrDGRI (by Yu .G. Filias and Yu. I. Petrash, 2002).

There are about 50 deposits in Bilche-Volytsa oil- and gas-bearing area, and only two of them contain petroleum (Kokhanivka and Lopushna areas). There are (Vyshnya and Orchovychy area) deposits, which contain oil and gas fields. Separate fields (seventeen deposits) contain gas-condensate in small amounts. The drilling range of the region is more than $100 \mathrm{~m} / \mathrm{km}^{2}$, however it remains very perspective [6].

In the last years new facts obtained from the wells yields enhance our understanding about the distributions of the geothermic parameters [7, 11]. As a result of the geothermic materials treatment [7, 14] the schematic map [15] of the temperature background values distribution on the cross-section $2000 \mathrm{~m}$ was modified. In the frames of the Carpathi- an Fore deep the temperatures at a depth of $-2000 \mathrm{~m}$ altered from $100^{\circ} \mathrm{C}$ to $65^{\circ} \mathrm{C}$, in the north -west and south-east respectively.

More heated north-west region is distinguished in distribution of the geothermic parameters, whereas the south-east region is less heated. The maximum temperatures are noted along the line of gas structures, which are related to north-west bed part of the outer zone. Averaged geothermal gradient equals $2.6^{\circ} \mathrm{C} / 100 \mathrm{~m}$ in the north-western part, increasing on the north-western edge to 3$3.5^{\circ} \mathrm{C} / 100 \mathrm{~m}$. In the east-south part geothermal gradient is $2.6^{\circ} \mathrm{C} / 100 \mathrm{~m}$ (Fig. 1).

On the basis of the bore-hole studies the most accurate measurements of stratum pressures and temperatures in sediments were considered (Table 1) and their graphs were drawn (Fig. 2, Fig. 3)

In the north-western deep part of the region (Kruchenychy-Lopushna), at the depth of approximately 1800-2000 m, stratum pressures are almost equal to hydrostatic (conventional) ones, that is they increase $10 \mathrm{MPa} / 1.0 \mathrm{~km}$. A consequent increase in the ratio of formation pressure to hydrostatic (conventional) pressure is noticed below. The ratio is named as a hydrostatic coefficient and reaches 1.4 at $4.0 \mathrm{~km}$ depth and $1.5-1.7$ at depth of $5 \mathrm{~km}$. (Fig. 2).

In the south-east up-lifted part of the region the stratum pressures (in all the limits of depths) are nearly the same as hydrostatical, thus, they increase approximately $10 \mathrm{MPa} / 1.0 \mathrm{~km}$ (Fig. 3).

The hydrostatic coefficient $\left(\mathrm{P}_{\mathrm{st}} / \mathrm{P}_{\mathrm{ch}}\right)$ depends on the structural-tectonic peculiarities of the studied area (Fig. 4).

On the whole, the phase state of the hydrocarbon systems is determined by the thermobaric conditions of bedding fields in rock formations. Two basic factors influence on the phase state of hydrocarbons in the bowels of the Earth. They are: 1) temperature increase diminishes molecular mass of oil as a result of destructive processes, and 2) pressure that is a consolidating factor and interferes with the process of high molecular chains destruction. Thus, it is advisable to take into account the simultaneous action of these thermodynamics factors [16]. For example, a thermobaric coefficient, which describes the phase state of hydrocarbon mixture as function of temperature and density, is offered in the paper [17].

Explaining patterns of spatial distribution of hydrocarbons and separate prognostication of oiland gas-bearingness zones in the sequence of sedimentary complex the attempt to take into account except temperatures and pressures other parameters characterizing hydrocarbon beds were realized. They must be, first of all, rather ordinary to give complete information about their numerical values. Secondly, the values of parameters must be set for all considered systems of hydrocarbons, namely: natural gas- 


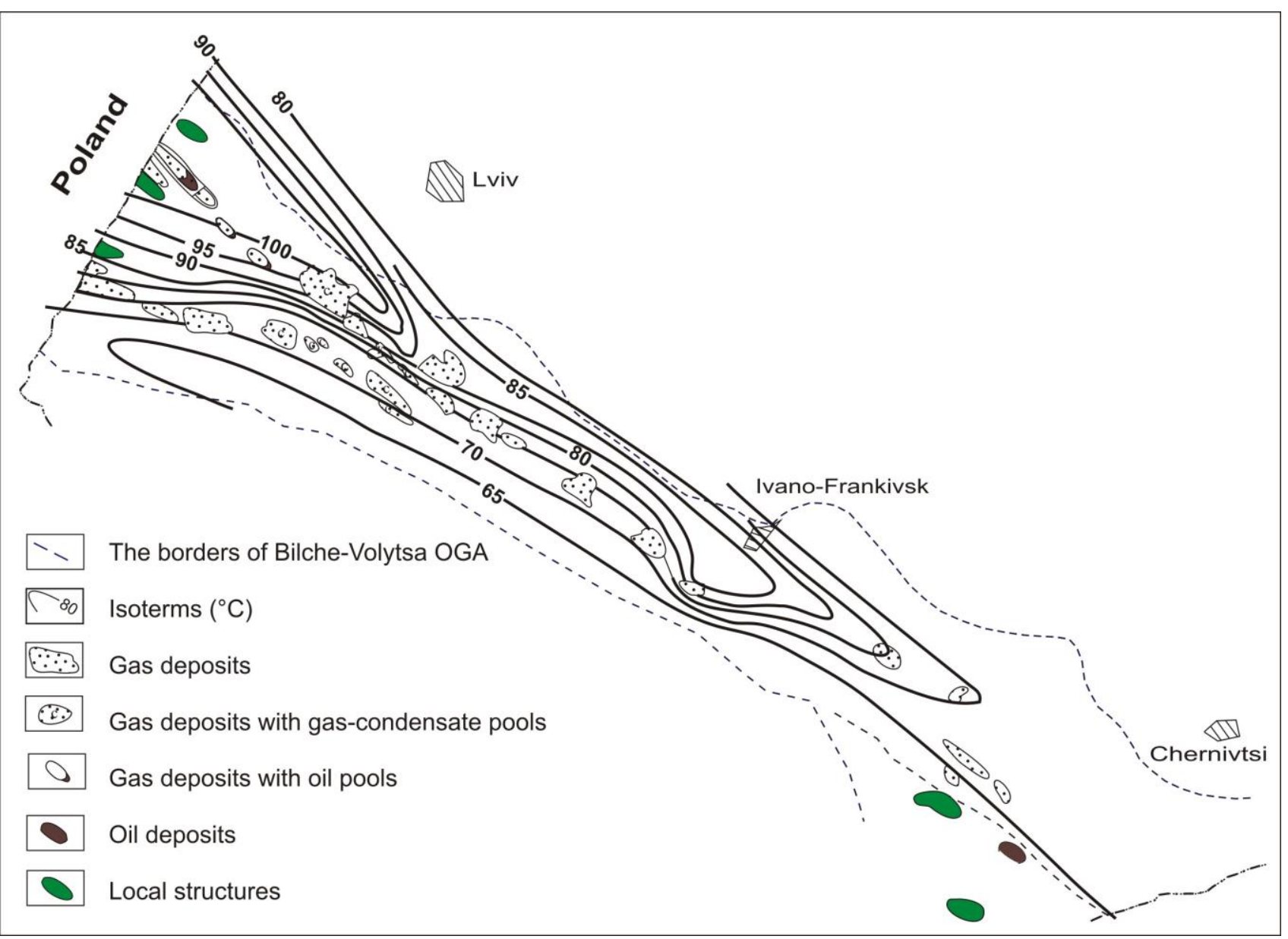

Fig. 1. Schematic geotemperature map at the depth of $-2000 \mathrm{~m}$ in the frames of Bilche-Volytsa oil- and gas-bearing area

Table 1

Stratum pressures and temperatures at the depths of Bilche-Volytsa oil- and gas-bearing area

\begin{tabular}{|c|c|c|c|c|c|c|c|}
\hline $\begin{array}{c}\text { Deposit } \\
\text { (area) }\end{array}$ & $\begin{array}{c}\text { Depths } \\
\text { of } \\
\text { measure, m }\end{array}$ & $\begin{array}{l}\text { Stratum } \\
\text { pressure, } \\
\mathrm{MPa}\end{array}$ & \begin{tabular}{|} 
Stratum tem- \\
perature, \\
$\mathrm{K} /{ }^{0} \mathrm{C}$
\end{tabular} & $\begin{array}{c}\text { Deposit } \\
\text { (area) }\end{array}$ & $\begin{array}{c}\text { Depths } \\
\text { of } \\
\text { measure, } \mathrm{m}\end{array}$ & $\begin{array}{c}\text { Stratum } \\
\text { pressure, } \\
\mathrm{MPa}\end{array}$ & $\begin{array}{c}\text { Stratum } \\
\text { temperature, } \\
\mathrm{K} /{ }^{\circ} \mathrm{C}\end{array}$ \\
\hline 1 & 2 & 3 & 4 & 1 & 2 & 3 & 4 \\
\hline \multicolumn{4}{|c|}{ North-western part } & Nyklovychy & 1277 & 12,41 & $321 / 48$ \\
\hline \multirow{5}{*}{ Vyzhomlya } & 788 & 7,10 & $312 / 39$ & Novosilky & 1947 & 21,18 & $348 / 75$ \\
\hline & 952 & 9,32 & $315 / 42$ & Pynyany & 2070 & 24,68 & $337 / 64$ \\
\hline & 1170 & 11,20 & $322 / 49$ & Sadkovychy & 995 & 9,51 & $311 / 39$ \\
\hline & 1286 & 12,24 & $325 / 52$ & \multirow[t]{2}{*}{ Svydnytsa } & 340 & 3,44 & $295 / 22$ \\
\hline & 1380 & 13,60 & $328 / 55$ & & 733 & 7,16 & $308 / 35$ \\
\hline \multirow[t]{5}{*}{ Vyshnya } & 637 & 6,73 & $303 / 30$ & \multirow[t]{2}{*}{ Susoliv } & 2680 & 36,59 & $359 / 88$ \\
\hline & 976 & 9,57 & $314 / 41$ & & 2833 & 35,73 & $363 / 92$ \\
\hline & 1054 & 10,51 & $317 / 44$ & \multicolumn{4}{|c|}{ South-eastern part } \\
\hline & 1298 & 12,09 & $325 / 52$ & \multirow[t]{2}{*}{ Yablunivka } & 980 & 10,86 & $308 / 35$ \\
\hline & 1695 & 16,16 & $338 / 65$ & & 1280 & 11,60 & $315 / 42$ \\
\hline \multirow[t]{3}{*}{ Gai } & 1326 & 12,36 & $320 / 47$ & \multirow[t]{2}{*}{ Cheremkhiv } & 150 & 1,38 & $288 / 15$ \\
\hline & 1673 & 16,26 & $326 / 53$ & & & & \\
\hline & 1835 & 17,36 & $333 / 60$ & \multirow[t]{2}{*}{ Bogorodchany } & 1090 & 10,35 & $306 / 33$ \\
\hline Gorodoc & 663 & 6,42 & $307 / 34$ & & 1235 & 11,17 & $313 / 40$ \\
\hline \multirow[t]{3}{*}{ Grudiv } & 475 & 4,33 & $300 / 27$ & \multirow[t]{3}{*}{ Kosiv } & 85 & 0,66 & $285 / 12$ \\
\hline & 899 & 9,01 & $308 / 35$ & & 160 & 1,05 & $289 / 16$ \\
\hline & 1201 & 11,20 & $319 / 46$ & & 440 & 4,19 & $293 / 20$ \\
\hline
\end{tabular}


Table 1 continuation

\begin{tabular}{|c|c|c|c|c|c|c|c|}
\hline 1 & 2 & 3 & 4 & 1 & 2 & 3 & 4 \\
\hline \multirow[t]{4}{*}{ Grushiv } & 1610 & 16,6 & $335 / 62$ & & 750 & 5,88 & $299 / 26$ \\
\hline & 2025 & 20,85 & $342 / 69$ & \multirow[t]{6}{*}{ Grynivka } & 580 & 5,53 & $295 / 22$ \\
\hline & 2290 & 23,52 & $351 / 78$ & & 690 & 6,42 & $299 / 26$ \\
\hline & 3307 & 35,80 & $371 / 98$ & & 836 & 7,55 & $303 / 30$ \\
\hline \multirow[t]{7}{*}{ Zaluzhany } & 1094 & 10,70 & $308 / 35$ & & 1010 & 9,23 & $308 / 35$ \\
\hline & 1478 & 15,40 & $329 / 56$ & & 1135 & 10,11 & $310 / 37$ \\
\hline & 2007 & 22,05 & $335 / 62$ & & 1350 & 12,21 & $314 / 41$ \\
\hline & 2660 & 29,18 & $352 / 79$ & \multirow[t]{2}{*}{ Debeslavychy } & 129 & 1,22 & $287 / 14$ \\
\hline & 2950 & 42,48 & $360 / 87$ & & 298 & 2,74 & $291 / 18$ \\
\hline & 3295 & 44,59 & $371 / 98$ & \multirow[t]{3}{*}{ Kovalivka } & 933 & 10,65 & $308 / 35$ \\
\hline & 3430 & 54,94 & $379 / 106$ & & 1550 & 15,34 & $319 / 46$ \\
\hline \multirow[t]{2}{*}{ Letnya } & 1186 & 11,18 & $321 / 43$ & & 2050 & 21,92 & $332 / 59$ \\
\hline & 1566 & 15,27 & $328 / 55$ & \multirow[t]{2}{*}{ Krasnoilsk } & 780 & 5,78 & $302 / 29$ \\
\hline \multirow[t]{6}{*}{ Maynychy } & 2415 & 29,50 & $346 / 73$ & & 1221 & 10,41 & $316 / 43$ \\
\hline & 2887 & 37,18 & $361 / 88$ & \multirow[t]{2}{*}{ Pylypiv } & 238 & 2,02 & $290 / 17$ \\
\hline & 3034 & 34,11 & $368 / 85$ & & 473 & 4,26 & $297 / 24$ \\
\hline & 3243 & 48,07 & $371 / 98$ & \multirow[t]{2}{*}{ Chornoguzy } & 591 & 5,12 & $299 / 26$ \\
\hline & 3564 & 49,36 & $387 / 114$ & & 1170 & 9,03 & $315 / 42$ \\
\hline & 3813 & 61,70 & $394 / 121$ & \multirow[t]{2}{*}{ Kadobna } & 210 & 1,84 & $293 / 20$ \\
\hline \multirow[t]{4}{*}{ Lopushna } & 4180 & 70,93 & $373 / 100$ & & 740 & 7,16 & $300 / 27$ \\
\hline & 4500 & 69,34 & $378 / 105$ & \multirow[t]{3}{*}{ Sheremeta } & 903 & 9,11 & $304 / 31$ \\
\hline & 5036 & 78,16 & & & 1095 & 10,86 & $308 / 35$ \\
\hline & 5136 & 77,03 & & & & & \\
\hline
\end{tabular}

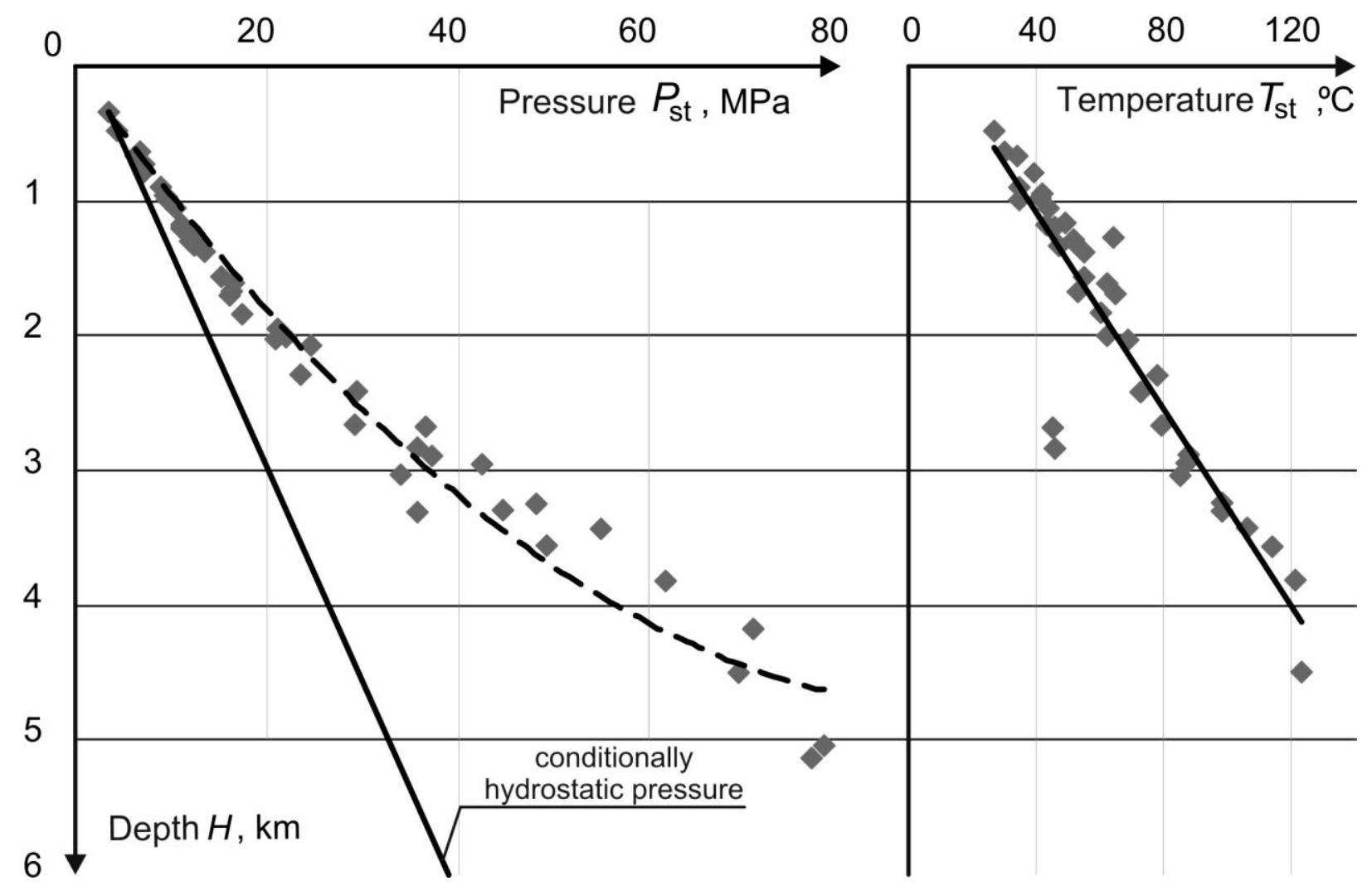

Fig. 2. Dependences of stratum pressures and temperatures in sediments upon the depths in the north-western part of the Bilche-Volytsa oil- and gas-bearing area 


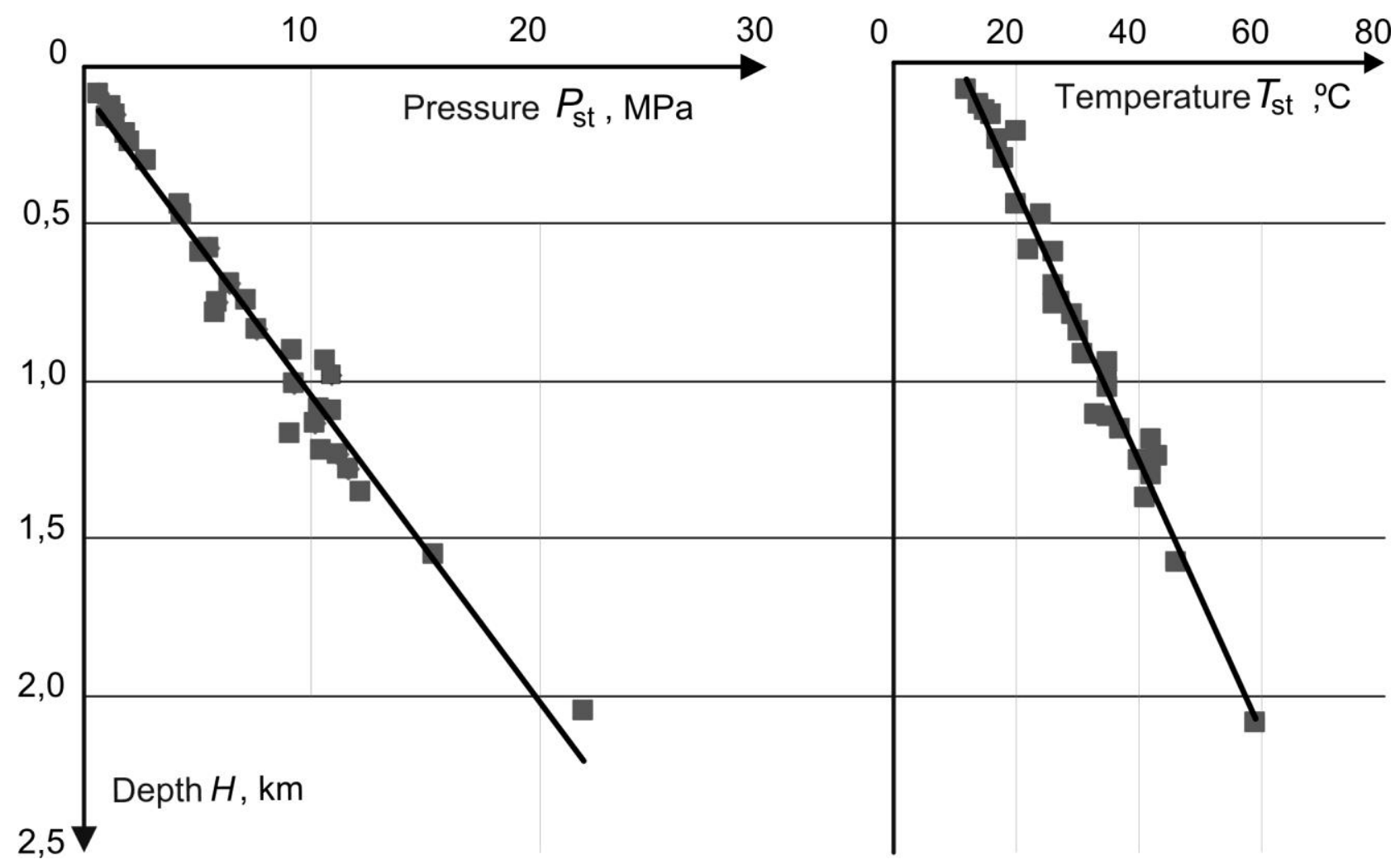

Fig. 3. Dependences of stratum pressures and temperatures in sediments upon the depths in the south-eastern part of Bilche-Volytsa oil- and gas-bearing area

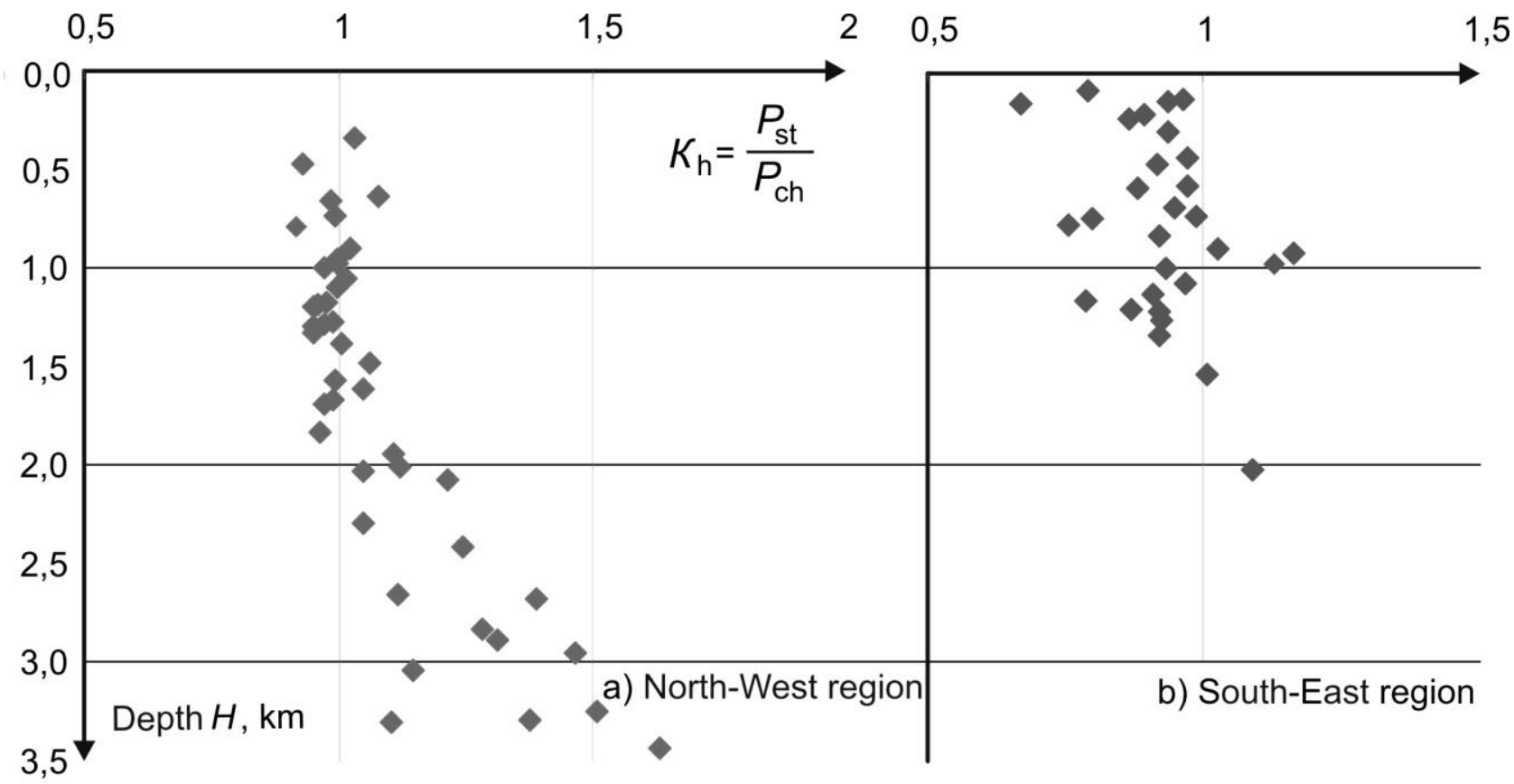

\section{BILCHE-VOLYTSA OIL- AND GAS-BEARING AREA}

Fig. 4. Graphs of the hydrocarbon fields distribution as a function of the hydrostatic coefficient and the depth.

es, gas-condensate and oil. Among such parameters most substantial for description of geological environment are: temperature and pressure, depth of stratum bedding, the average density and molar mass of stable hydrocarbons mixture, taking into account their reliability and availability.
The values of pressure and temperature in a stratum are the result of direct monitoring by using deep devices or interpolations of already available data for a region, and average density and average molar mass are determined experimentally or calculated. 
This task is solved by the method of dimensional analysis, which, in turn, is an important tool at the modeling of the real systems on the basis of similitude (theory of similarity). As it follows from the first theorem of similitude, in case physical processes are similar to each other, then the same dimensionless criteria of similarity of these processes have an identical value. So, the solution to the task is carrying out such dimensionless criteria $[18,19]$. Applying the fundamental for the dimensional analysis $\pi$-theorem [20] we obtain the following common expression:

$$
\begin{array}{r}
F\left(P^{a_{1}}, \rho^{a_{2}}, M^{a_{3}}, g^{a_{4}}, R^{a_{5}}, T^{a_{6}}, H^{a_{7}}\right) \equiv 0 \\
\left(\frac{\mathrm{kg}}{\mathrm{m} \cdot \mathrm{s}^{2}}\right)^{a_{1}} \cdot\left(\frac{\mathrm{kg}}{\mathrm{m}^{3}}\right)^{a_{2}} \cdot\left(\frac{\mathrm{kg}}{\mathrm{mol}}\right)^{a_{3}} \cdot
\end{array}
$$

where $\mathrm{P}$ - stratum pressure, $\rho$ - density, $\mathrm{M}$ - molar mass of hydrocarbons mixture, $\mathrm{g}$ - gravity of Earth, $\mathrm{R}$ - ideal gas constant, $\mathrm{T}$ - stratum temperature, $\mathrm{H}$ the depth of the deposit, a1-a7 - arbitrary degrees determined by the conditions of dimensionless of the function.

The functional dependency (F) between the selected parameters generally is implicit, that is one parameter couldn't be necessarily expressed in terms of the others. Entering gravity of Earth, equal to 9.81 $\mathrm{m}^{2} / \mathrm{s}$ and ideal gas constant $\mathrm{R}=8.31 \mathrm{~J} / \mathrm{mol}^{*} \mathrm{~K}$ is made to bring the system in the SI units. We put the dimensions into the function (1), a result of multiplication of which must be identical to one, i.e. dimensionless:
On the second stage we distinguish all independent dimensions which are present in a formula (2) and compose a system of equations that looks like that:

$$
\begin{gathered}
\text { kg: } \quad a_{1}+a_{2}+a_{3}+a_{5}=0 \\
\text { m: }-a_{1}-3 a_{2}+a_{4}+2 a_{5}+a_{7}=0 \\
\text { s: }-2 a_{1}-2 a_{4}-2 a_{5}=0 \\
\text { mol: }-a_{1}-a_{5}=0 \\
\text { K: }-a_{5}+a_{6}=0
\end{gathered}
$$

Solving the system (3) we obtain the following expression:

$$
F\left(\left[\frac{P M}{\rho R T}\right]^{a} \cdot\left[\frac{M g H}{R T}\right]^{b}\right) \equiv 0
$$

abbreviated version is:

$$
F\left(Z_{1}^{a}, Z_{2}^{b}\right) \equiv 0
$$

In equation (4) $Z_{1}$ and $Z_{2}$ are criteria that allow to solve our problem, and the degrees $a$ and $b$ are selected so that the relationship between the criteria expressed by the simplest means. In case of equality (4) this is an equation of straight line, degree $\mathrm{a}=0.25$ and $\mathrm{b}=0.5$. At solving the system (3) an- other criterion $-\mathrm{Z}_{3}$ was obtained, which submits to the next dependences:

$$
\frac{Z_{1}}{Z_{2}}=Z_{3}=K_{h} \frac{\rho_{\text {water }}}{\rho}
$$

where $K_{h}$ - hydrostatic factor.

On the whole, the criteria got at decision of the task are expressed so:

$$
Z_{1}=\left[\frac{\mathrm{PM}}{\rho \mathrm{RT}}\right] ; Z_{2}=\left[\frac{\mathrm{MgH}}{\mathrm{RT}}\right] ; Z_{3}=\left[\frac{\mathrm{P}}{\rho \mathrm{gH}}\right]
$$

The criterion of "compression" $\mathrm{Z}_{1}$ shows the ratio of hydrocarbon system compression energy to the energy of thermal motion and equals one for the ide-

\begin{tabular}{|c|c|c|c|c|}
\hline$Z_{2}^{b} Z_{1}^{a}$ & $0,7-1,0$ & $1,0-1,2$ & $1,2-1,6$ & $1,6-5,0$ \\
\hline $0-0,6$ & - & - & - & $\mathrm{G}$ \\
\hline $0,6-1,4$ & $\mathrm{G} / \mathrm{C}$ & $\mathrm{G} / \mathrm{C}$ & - & - \\
\hline $1,4-1,7$ & - & $\mathrm{O}$ & $\mathrm{O}$ & - \\
\hline
\end{tabular}
al gas. "Hypsometric" criterion $Z_{2}$ is the ratio of the potential energy of the mass $M$ risen to the height $\mathrm{H}$ to the energy of thermal motion. In Figure 5 dotted lines mark areas of the $Z_{1}$ and $Z_{2}$ criteria values to which the different types of hydrocarbons of BilcheVolytsa oil- and gas-bearing area correspond.

The areas of numerical values $Z_{1}$ and $Z_{2}$ criteria, that describe the phase state of hydrocarbon $(a b-$ breviation in the table: $\mathrm{G}-$ gas, $\mathrm{O}-$ oil and $\mathrm{G} / \mathrm{C}-$ gas-condensate), were identified: 


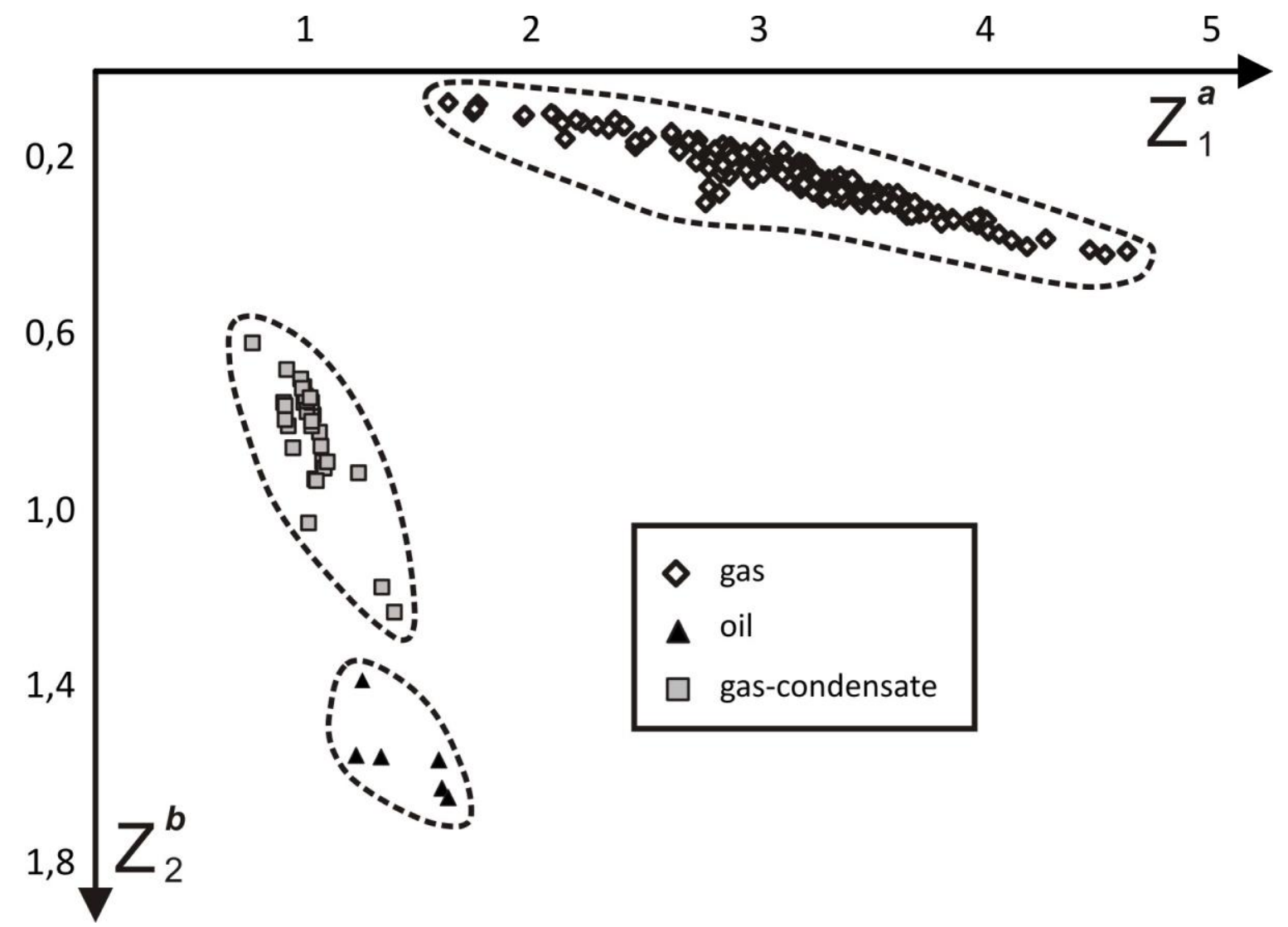

Fig. 5. Dependence of the hydrocarbons system types on values $Z_{1}$ and $Z_{2}$ criteria.

The data shown in Fig. 5 and the table indicate the boundaries of hydrocarbons system types distribution from values of criteria $Z_{1}$ and $Z_{2}$, which makes them a reliable tool to establish the phase state of hydrocarbon deposits.

\section{Conclusions}

1. For the first time the dimensionless criteria $Z_{1}$ and $\mathrm{Z}_{2}$, which characterize the hydrocarbon systems and allow to set the phase state of the hydrocarbons system in the oil- and gas-bearing sedimentary complexes having the information about the depth of the deposit, density and molar mass of hydrocarbons as well as reservoir temperature and pressure, are determined.

2. According to the distribution of geothermic parameters two areas differ rather distinctly: more heated north-western region and less heated south-eastern one. The maximum temperatures are noted along the line of gas structures, which are related to the north-west near platform part of the outer zone.

3. It has been established that at depths more than $4000 \mathrm{~m}$, depending on geological conditions, there are deviations of value $\mathrm{Z}_{1}{ }^{\mathrm{a}}$ in limits $20 \%$ from the average one.

4. Universality of $\pi$-theorem has proved the possibility to enter other parameters of hydrocarbons systems in the sedimentary complex rocks. It significantly improves and expands determination of similarity criteria required for predicting the hydrocarbons phase state in various geological conditions.

\section{References}

1. Брусиловский, А. И. Фазовые превращения при разработке месторождений нефти и газа / А. И. Брусиловский. - Москва : Издательский дом "Грааль", 2002. - 579 с.

2. Лапиин, В. И. Фазовые превращения углеводородных нефтегазоконденсатных систем / В. И. Лапиин, А. Н. Волков, А. А. Константинов // Научно-технический сборник "Вестник газовой науки". - 2014. - № 2 (18). - C. $120-128$.

3. Калашников, О.В. Моделирование фазового поведения углеводородов: выбор уравнения состояния / О. В. Калашников // Экотехнологии и ресурсосбережение. - 2003. - №1. - С. 22-30.

4. Орешкин, И. В. Обоснование критериев прогноза фазового состояния пластовых углеводородных смесей / И. В. Орешкин, Е. В. Постнова, А. А. Пятаев // Теоретические основы и технологи поисков и разведки нефти и газа. - 2013. - № 4. - с. 29-33.

5. Отбор проб и аналіз природних газов нефтегазоносных басейнов / В. А. Ванюшин, Л. М. Завьялова, Г. С. Коробейник и др. - Москва : Недра, 1984. - 239 с.

6. Атлас родовищ нафти і газу Украӥни. Західний нафтогазоносний регіон / [наук. ред.: В. О. Федишин та ін.]. - Українська нафтогазова академія. - Львів: Центр Європи. - Т. - 1998. - 277 с. 
7. Новосилецикий, Р. М. Геотермический режим и нефтегазоносность недр Украинь / Р. М. Новосилецкий, А. Ю. Полутранко // Геотермические модели геологических структур. - СПб., 1991. - C.142-152.

8. Осадчий, В. Г. Геотермические критерии нефтегазоносности недр / В. Г. Осадчий, А. И. Лурье, В. Ф. Ерофеев. - К. : Наукова думка, 1976. -144 с.

9. Колодий, В. В. Геотермобарические условия и нефтегазоносность водонапорньх бассейнов / В. В. Колодий // Геология и геохимия горючих ископаемых. - 1979. - №2 (52). - C. 3-8.

10. Колодій, В. В. Нафтогазова гідрогеологія : підруч. [для студ. вищч. навч. закл.] / В. В. Колодій, І. В. Колодій, Б. Й. Маєвський. - Івано-Франківськ: Факел, 2009. -184 с.

11. Крупский, Ю. З. Геодинамічні умови формування і нафтогазоносність Карпатського і Волино-Подільського району України / Ю. 3. Крупский. - К. : УкрДГРІ, 2001. - 144 c.

12. Новосилецкий, Р. М. Геогидродинамические и геохимические условия формирования залежей нефтей и газа Украинь / Р. М. Новосилецкий. - Москва : Недра, 1975. - 228 с.

13. Ковальчук, Н. Р. Прогнозная оценка физических параметров пластовых нефтей на глубинах 4000-7000 м 8 Предкарпатском регионе / Н. Р. Ковальчук, Ю. И. Филяс // Новые данные по геологии и нефтегазоносности УССР. - Львов, 1973. - С. 74-79.

14. Гуревич, Г. Р. Справочное пособие по расчету фазового состояния и свойств газоконденсатных смесей / Г. Р. Гуревич, А. И. Брусиловский. - Москва : Недра, 1984. - 264 с.

15. Кутас, Р. И. Тепловое поле Украины / Р. И. Кутас, В. В. Гордиенко. - К. : Наукова думка, 1971. - 140 c.

16. Cimaszewski, L. Akumulacja weglowodow pochodna naturalnoj termodynamiki / L. Cimaszewski // Nafta. - 1976. № 2. - Pp. 37-41.

17. Геолого-геохимические проиессы в газоконденсатных месторождениях и ПХГ / В. И. Петренко, В. В. Зиновьев, В. Я. Зленко и др. - Москва : "Недра", 2003. - 511 с.

18. Кутателадзе, С. С. Анализ подобия и физическое моделирование / С. С. Кутателадзе. - Новосибирск : Наука, 1986. - 295 с.

19. Розовский, Л. Б. Введение в теорию геологического подобия и моделирования / Л. Б. Розовский. - Москва : Недра, 1969. - 127 c.

20. Седов, Л. И. Методы подобия и размерности в механике / Л. И. Седов. - Москва : Наука, 1977. - 440 с. 